\title{
PTGFRN Gene
}

National Cancer Institute

\section{Source}

National Cancer Institute. PT GFRN Gene. NCI Thesaurus. Code C102811.

This gene is involved in the inhibition of prostaglandin binding. 